\title{
Modelling soil organic carbon stocks in global change scenarios: a CarboSOIL application
}

\author{
M. Muñoz-Rojas ${ }^{1,2,3, *}$, A. Jordán ${ }^{4}$, L. M. Zavala ${ }^{4}$, F. A. González-Peñaloza ${ }^{5}$, D. De la Rosa ${ }^{6}$, R. Pino-Mejias ${ }^{7}$, and \\ M. Anaya-Romero ${ }^{8}$ \\ ${ }^{1}$ Plant Biology, University of Western Australia, Perth 6009, Australia \\ ${ }^{2}$ Kings Park and Botanic Garden, Perth 6005, Australia \\ ${ }^{3}$ Department of Environment and Agriculture, Curtin University, 6845 Perth, Australia \\ ${ }^{4}$ MED_Soil Research Group, Dpto. de Cristalografía, Mineralogía y Química Agrícola, Facultad de Química, University of \\ Seville, 41012 Seville, Spain \\ ${ }^{5}$ Soil Erosion Research Group (SEDER), Departament de Geografia, Universitat de València, 46022 Valencia, Spain \\ ${ }^{6}$ Instituto de Recursos Naturales y Agrobiología de Sevilla (CSIC), 41012 Seville, Spain \\ ${ }^{7}$ Department of Statistics, University of Seville, Av. Reina Mercedes s/n, 41012 Seville, Spain \\ ${ }^{8}$ Evenor-Tech, CSIC Spin-off, Instituto de Recursos Naturales y Agrobiología de Sevilla (CSIC), Seville 41012, Spain \\ *Invited contribution by M. Muñoz-Rojas, recipient of the EGU Young Scientists Outstanding Poster Paper Award 2012.
}

Correspondence to: M. Muñoz-Rojas (miriam.munoz-rojas@uwa.edu.au)

Received: 22 May 2013 - Published in Biogeosciences Discuss.: 4 July 2013

Revised: 28 October 2013 - Accepted: 5 November 2013 - Published: 13 December 2013

\begin{abstract}
Global climate change, as a consequence of the increasing levels of atmospheric $\mathrm{CO}_{2}$ concentration, may significantly affect both soil organic $\mathrm{C}$ storage and soil capacity for $\mathrm{C}$ sequestration. CarboSOIL is an empirical model based on regression techniques and developed as a geographical information system tool to predict soil organic carbon (SOC) contents at different depths. This model is a new component of the agro-ecological decision support system for land evaluation MicroLEIS, which assists decision-makers in facing specific agro-ecological problems, particularly in Mediterranean regions. In this study, the CarboSOIL model was used to study the effects of climate change on SOC dynamics in a Mediterranean region (Andalusia, S Spain). Different downscaled climate models were applied based on BCCR-BCM2, CNRMCM3, and ECHAM5 and driven by SRES scenarios (A1B, A2 and B2). Output data were linked to spatial data sets (soil and land use) to quantify SOC stocks. The CarboSOIL model has proved its ability to predict the short-, medium- and long-term trends (2040s, 2070s and 2100s) of SOC dynamics and sequestration under projected future scenarios of climate change. Results have shown an overall trend towards decreasing of SOC stocks in the upper soil sections
\end{abstract}

$(0-25 \mathrm{~cm}$ and $25-50 \mathrm{~cm})$ for most soil types and land uses, but predicted SOC stocks tend to increase in the deeper soil section $(0-75 \mathrm{~cm})$. Soil types as Arenosols, Planosols and Solonchaks and land uses as "permanent crops" and "open spaces with little or no vegetation" would be severely affected by climate change with large decreases of SOC stocks, in particular under the medium-high emission scenario A2 by 2100 . The information developed in this study might support decision-making in land management and climate adaptation strategies in Mediterranean regions, and the methodology could be applied to other Mediterranean areas with available soil, land use and climate data.

\section{Introduction}

Global climate is changing as a consequence of the increasing levels of atmospheric $\mathrm{CO}_{2}$ concentration and global mean temperatures (IPCC, 2007). Soil organic carbon (SOC) is strongly influenced by climate conditions, and SOC stocks are determined by the balance between the total amount of $\mathrm{C}$ released to the atmosphere in the form of $\mathrm{CO}_{2}$ and the total 
amount withdrawn from the atmosphere as net $\mathrm{C}$ inputs to the soil (Janssens et al., 2005). Carbon stored in soils is the largest $\mathrm{C}$ pool in most terrestrial ecosystems holding approximately $1500 \mathrm{PgC}$ in the top metre (Batjes, 1996), roughly twice the amount of $\mathrm{C}$ in the atmosphere and three times the amount in vegetation (Lal, 2004). Thus, small changes in the SOC pool could have a vast impact on atmospheric $\mathrm{CO}_{2}$ concentrations. Only a difference of $10 \%$ in SOC would equal the total anthropogenic $\mathrm{CO}_{2}$ emissions of the last $30 \mathrm{yr}$ (Kirschbaum, 2000).

Global climate change may significantly affect both SOC storage and soil capacity for $\mathrm{C}$ sequestration. Increases in soil temperature and atmospheric $\mathrm{CO}_{2}$ have been related to higher decomposition rates and changes in net primary productivity (NPP). Increased temperatures might enhance the release of $\mathrm{CO}_{2}$ to the atmosphere from SOC, leading to higher $\mathrm{CO}_{2}$ levels and accelerated global warming (Davidson and Janssens, 2006). On the other hand, soil carbon sequestration, considered as the net removal of $\mathrm{CO}_{2}$ from the atmosphere, could help to alleviate the problem of global warming and climate change. Carbon sequestration in terrestrial ecosystems is one of the most important ecosystem services due to its role in climate regulation (IPCC, 2007). At the same time, it provides important benefits for soils, crops and environment quality associated with increasing levels of SOC carbon such as improved soil structure, soil fertility, water holding capacity, infiltration capacity, water use efficiency and soil biological health (which results in higher nutrient cycling and availability). Additionally, soil organic C prevents from soil erosion and desertification and enhances bio-diversity. Soil carbon accumulation capacity should be considered regarding adaptation strategies to climate change, in view of the high resilience of soils with an adequate level of organic $\mathrm{C}$ to a warming, drying climate (Christensen et al., 2011). However, the potential effects of climate change on SOC dynamics are still largely uncertain (Álvaro-Fuentes and Paustian, 2011; Powlson, 2005; Zaehle et al., 2007). In order to formulate adaptation policies in response to climate change impacts, it is crucial to assess soil carbon stocks and evaluate their dynamics in future climate scenarios (Chiesi et al., 2010).

Soil carbon contents in Mediterranean areas are usually lower than in temperate regions because of the particular climate features of these regions such as seasonal dryness (Jones et al., 2005). Mediterranean ecosystems are particularly sensitive to climate change because of the predicted reduced water availability and the increase of desertification risk (IPCC, 2007). These factors might lead to a decrease of plant productivity and a lower $\mathrm{C}$ input to soils. As a consequence, most Mediterranean soils would be depleted of SOC which would translate in low soil fertility (Aguilera et al., 2013). Therefore, it is crucial to study the effects of climate change on SOC contents of different land use and soil types of Mediterranean areas in order to prevent SOC decreases by adequate land planning and adoption of management practices.

Different approaches have been used to assess the impact of global warming and climate change on SOC stocks. Models are effective tools to assess $\mathrm{C}$ stocks and $\mathrm{C}$ dynamics (Falloon and Smith, 2003; Falloon et al., 2002; Jones et al., 2005; Paustian et al., 1997), which makes them appropriate for C reporting and assessment studies. They are particularly useful as decision support systems (DSSs) on climate change issues (Smith et al., 2005). Modelling allows us to predict the short-, medium- and long-term trends of SOC dynamics and SOC sequestration under projected future scenarios of climate change (Lucht et al., 2006; Smith et al., 2005; Wan et al., 2011), which is crucial in order to take measures for an adequate management in agroforestry ecosystems. By linking simulation models to spatial data sets (soils, land use), it is possible to determine current and future estimates of regional SOC stocks and SOC sequestration (Batjes, 2006; Falloon et al., 1998; Hashimoto et al., 2012). Moreover, patterns in SOC dynamics related to soil and land use features can be analysed.

Scenario-driven impact assessments require detailed spatial and temporal data on the projected future climate. Several global climate models (GCMs) have been developed, providing adequate simulations of atmospheric general circulation at the continental scale and projecting precipitation, temperature, and other climate variables (Mitchel et al., 2004). GCMs require information on future greenhouse gas (GHG) emissions generated by socio-economic scenarios and models. The IPCC SRES (Special Report on Emissions Scenarios) makes available estimates of future anthropogenic $\mathrm{CO}_{2}$ emission. These scenarios contain various driving forces of climate change and are widely used to assess potential climate changes (Christensen et al., 2011).

In the past years, several soil carbon models such as CENTURY (Parton et al., 1987) or RothC (Coleman and Jenkinson, 1999) have been applied in the Mediterranean region (Alvaro-Fuentes et al., 2012; Francaviglia et al., 2012; Lugato and Berti, 2008; Mondini et al., 2012). Nonetheless, few studies consider the different sections along the soil profile in the assessment of projected SOC stocks in the Mediterranean region. Most of the research on soil carbon modelling focuses on topsoil or upper layer, but there is evidence that in deeper soil layers a considerable amount of carbon can be stored, and this form of $\mathrm{C}$ has proven to be more stable (Batjes, 1996; Jobbágy and Jackson, 2000; Muñoz-Rojas et al., 2012a; Tarnocai et al., 2009). Furthermore, climate change will affect SOC stocks differently under diverse land uses and soil types. Each soil type and land use show different properties (Albaladejo et al., 2013; Muñoz-Rojas et al., 2012a) and consequently different vulnerability to climate conditions and $\mathrm{C}$ sequestration capacity. Consequently there is a need to predict the potential SOC stocks of the different soil layers according to different soil types and under different land uses (Christensen et al., 2011). 


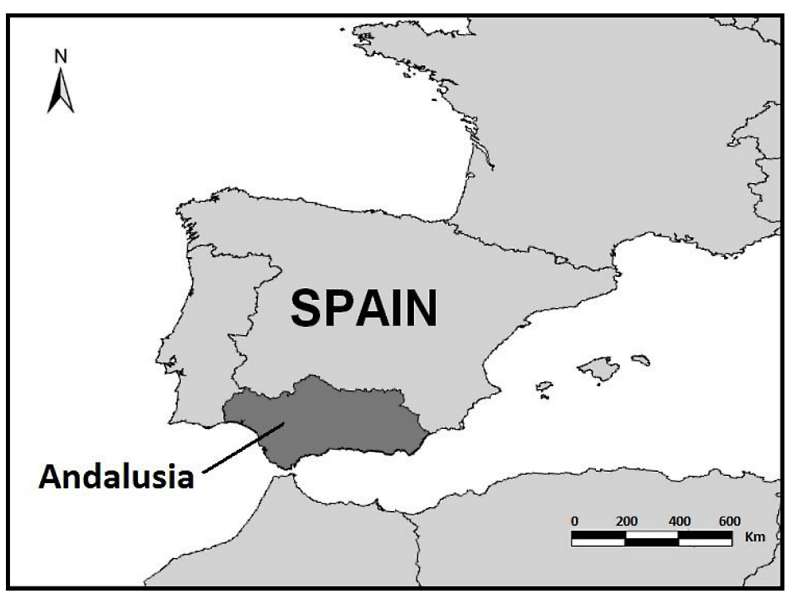

Fig. 1. Study area.

In this study, the CarboSOIL model together with climate outputs from different GCMs (BCCR-BCM2, CNRMCM3, and ECHAM5) driven by SRES scenarios (A2, A1B and B2) was used to study the effects of climate change on SOC dynamics in a Mediterranean region (Andalusia, S Spain, Fig. 1). The main objectives are as follows: (a) to predict SOC contents in future climate projections for different soil and land use types, (b) to obtain the spatial distribution and SOC stocks for different climate projections and (c) to determine CarboSOIL model sensitivity to climate variables.

\section{Materials and methods}

\subsection{CarboSOIL model description and application}

CarboSOIL is a land evaluation model for soil carbon accounting under global change scenarios (Anaya-Romero et al., 2012; Muñoz-Rojas, 2012). This model is part of a global project for developing a land evaluation model for assessment of soil $\mathrm{C}$ sequestration capacity, as a new component of the MicroLEIS decision support system (Anaya-Romero et al., 2011; De la Rosa et al., 2004). MicroLEIS DSS assists decision-makers with specific agro-ecological problems, and it was designed as a knowledge-based approach incorporating a set of information tools, linked to each other.

CarboSOIL was developed to simulate soil $\mathrm{C}$ dynamics of natural or cultivated systems under different scenarios of climate or land use change. The model is divided in four modules or submodels which predict soil organic carbon contents at different depths: (a) CarboSOIL25 $(0-25 \mathrm{~cm})$, (b) CarboSOIL50 (25-50 cm), (c) CarboSOIL75 $(50-75 \mathrm{~cm})$ and $(\mathrm{d})$ CarboSOILTOTAL $(0-75 \mathrm{~cm})$. The input variables to run the model are divided in (I) climate variables (mean winter/summer temperature and annual precipitation), (II) site variables (elevation, slope, erosion, type of drainage), (III) soil ( $\mathrm{pH}, N$, cation exchange capacity, sand/clay con- tent, bulk density and field capacity), and (IV) land use, with a total of 15 independent variables and a predictor variable (soil organic carbon) (Table 1).

CarboSOIL is an empirical model based on regression techniques. It was built with multiple linear regression in the total soil section $(0-75 \mathrm{~cm})$ and multiple linear regression with Box-Cox transformation techniques in the soil subsections (0-25, 25-50 and 50-75 cm) (Muñoz-Rojas, 2012). The list of variables with statistical parameters (coefficients and confidence intervals) is shown in Table 2, and Fig. 2 shows a conceptual diagram of the empirical model CarboSOIL. The model has been developed as a computer application in a geographical information system (GIS) environment using the Model Builder and Visual Basic applications of ArcGIS 10 (ESRI, 2011), which allow users to perform spatial analysis and to obtain output maps of SOC content under different scenarios. CarboSOIL submodels run independently as script tools in the ArcToolbox environment within the ArcGIS 10 software.

To assess SOC and SOC changes in Andalusia, southern Spain, under future climate scenarios, the CarboSOIL model has been applied to 1356 plots covering a range of soil types, land uses, site and climate conditions throughout the study area. Although CarboSOIL is applied at plot scale, output data can be linked to spatial data sets to perform spatial analysis and quantify SOC stocks.

\subsection{Study area}

Andalusia (southern Spain) covers an area of approximately $87000 \mathrm{~km}^{2}$ (Fig. 1). Climate is mostly Mediterranean type, characterized by the particular distribution of temperatures and precipitations. Annual rainfall values range between $170 \mathrm{~mm}$ and $>2000 \mathrm{~mm} \mathrm{yr}^{-1}$. Western Atlantic areas are more rainy and humid, while the eastern portion has a dry Mediterranean climate, almost desert. Average annual temperatures vary between $<10$ and $18^{\circ} \mathrm{C}$, although milder temperatures are observed at the coast. The annual evapotranspiration (ETo) ranges from 953.9 to $1460.4 \mathrm{~mm}$. There is a large altitudinal range in Andalusia, and elevation varies between 0 and 3479. The main soils in the area are Cambisols (33\%), Regosols (20\%), Luvisols (13\%) and Leptosols (11\%) (CSIC-IARA, 1989).

Most of the natural vegetation is Mediterranean forest, mainly oaks, pines and firs with dense riparian forests and Mediterranean shrubs. At present, approximately $44.1 \%$ of the region is occupied by agricultural areas and $49.8 \%$ by natural areas. Both urban and water spaces cover $3 \%$ of the area respectively (Bermejo et al., 2011). Agriculture has traditionally been based on wheat crops, olive trees and vineyards, but in recent decades they have been substituted with intensive and extensive crops (e.g. rice, sugar beet, cotton and sunflower). 
Table 1. CarboSOIL model input variables, units and sources.

\begin{tabular}{|c|c|c|c|c|}
\hline $\begin{array}{l}\text { Variable } \\
\text { type }\end{array}$ & $\begin{array}{l}\text { Variable } \\
\text { name }\end{array}$ & Code & Unit & Source and reference \\
\hline $\begin{array}{l}\text { Dependent } \\
\text { variable }\end{array}$ & Soil organic C & SOC & $\mathrm{Mgha}^{-1}$ & Jordán y Zavala (2009) and SDBm Plus database (2002) \\
\hline \multirow[t]{3}{*}{ Climate } & $\begin{array}{l}\text { Total } \\
\text { precipitation }\end{array}$ & PRPT & $\mathrm{mm}$ & $\begin{array}{l}\text { REDIAM-CLIMA } \\
\text { http://www.juntadeandalucia.es/medioambiente/site/web/rediam; } \\
\text { State Meteorological Agency (www.aemet.es) }\end{array}$ \\
\hline & Winter & TDJF & ${ }^{\circ} \mathrm{C}$ & \\
\hline & $\begin{array}{l}\text { Temperature } \\
\text { Summer } \\
\text { Temperature }\end{array}$ & TJJA & ${ }^{\circ} \mathrm{C}$ & \\
\hline \multirow[t]{4}{*}{ Site } & Elevation & ELEV & $\mathrm{m}$ & Digital elevation model of Andalusia, 100 m (ICA, 1999) \\
\hline & Slope & SLOP & $\%$ & \\
\hline & Drainage & DRAI & & Jordán and Zavala (2009) and SDBm Plus database (2002) \\
\hline & Soil erosion & SERO & & \\
\hline \multirow[t]{7}{*}{ Soil } & Nitrogen & NITRO & $\mathrm{g} / 100 \mathrm{~g}$ & \\
\hline & $\mathrm{pH}$ & PHWA & & \\
\hline & $\begin{array}{l}\text { Cation exchange } \\
\text { Capacity }\end{array}$ & CEXC & $\mathrm{meq} / 100 \mathrm{~g}$ & \\
\hline & Sand & SAND & $\mathrm{g} / 100 \mathrm{~g}$ & \\
\hline & Clay & CLAY & $\mathrm{g} / 100 \mathrm{~g}$ & \\
\hline & Bulk density & BULK & $\mathrm{g} / \mathrm{cc}$ & \\
\hline & Field capacity & FCAP & $\mathrm{g} / 100 \mathrm{~g}$ & \\
\hline Land use & $\begin{array}{l}\text { Land use/ } \\
\text { land cover }\end{array}$ & LULC & & $\begin{array}{l}\text { Land use and land cover map of Andalusia (2007); } \\
\text { SIOSE project (www.siose.es) }\end{array}$ \\
\hline
\end{tabular}

\subsection{Climate data and scenarios}

The CarboSOIL model requires the following climate parameters to run: annual precipitation $(\mathrm{mm})$, mean winter temperature (average of December, January and February monthly temperature, ${ }^{\circ} \mathrm{C}$ ) and mean summer temperature (average of June, July and August monthly temperature, $\left.{ }^{\circ} \mathrm{C}\right)$.

Climate data for baseline and future climate change scenarios were obtained from the time series of the CLIMA subsystem of the Environmental Information Network of Andalusia (REDIAM), which has integrated several databases from a set of over 2200 observatories since 1971. These data include climate spatial data sets in raster format for different SRES scenarios, obtained by statistical downscaling of different GCMs. The downscaling techniques are based on inverse distance interpolation and regression modelling of regional/local physiographic features.

Three GCMs were selected for the application of CarboSOIL, (a) BCCR-BCM2 (Bjerknes Centre for Climate Research, Norway), (b) CNRMCM3 (Centre National de Recherches Météorologiques, Météo France, France) and (c) ECHAM5 (Max Planck Institute for Meteorology, Germany). These three GCMs represent a spread of model characteristics and thus their scenario climates (Mitchell et al., 2004).

For each GCM, we obtained monthly temperature and annual precipitation under three different $\mathrm{CO}_{2}$ emissions sce- narios (AIB, B1, A2) as defined in the IPCC Fourth Assessment Report on emissions scenarios (Nakicenovic et al., 2000; IPCC, 2007). We selected climate series for four periods: 1961-2000 (baseline climate period), 2011-2040 (the "near-future" period), 2041-2070 (the "mid-future" period) and 2071-2100 (the "far-future" period). Data were extracted by using ArcGIS Spatial Analyst extension tool (ESRI, 2011).

\subsection{Site and soil data}

Elevation and slope data were extracted from the digital elevation model (DEM) of Andalusia with resolution of $100 \mathrm{~m}$ (ICA, 1999), which is derived from the topographic map of Andalusia (S 1:10000).

Type of drainage and active soil erosion processes (sheet erosion, rill erosion and gully erosion) were obtained from 1356 soil profiles reported and described by Jordán and Zavala (2009) and the SEISnet soil geo-databases (http:// www.evenor-tech.com/banco/seisnet/seisnet.htm). Selection of soil profiles was carried out considering homogeneous sampling and analysis methods. These geo-databases consist of descriptive and analytical data, including site attributes, horizon description, chemical and physical analysis.

Likewise, soil data were obtained from the 1356 soil profiles, and soil variables used in this study were soil depth $(\mathrm{cm})$, nitrogen $(\mathrm{g} / 100 \mathrm{~g}), \mathrm{pH}$, cation exchange capacity 


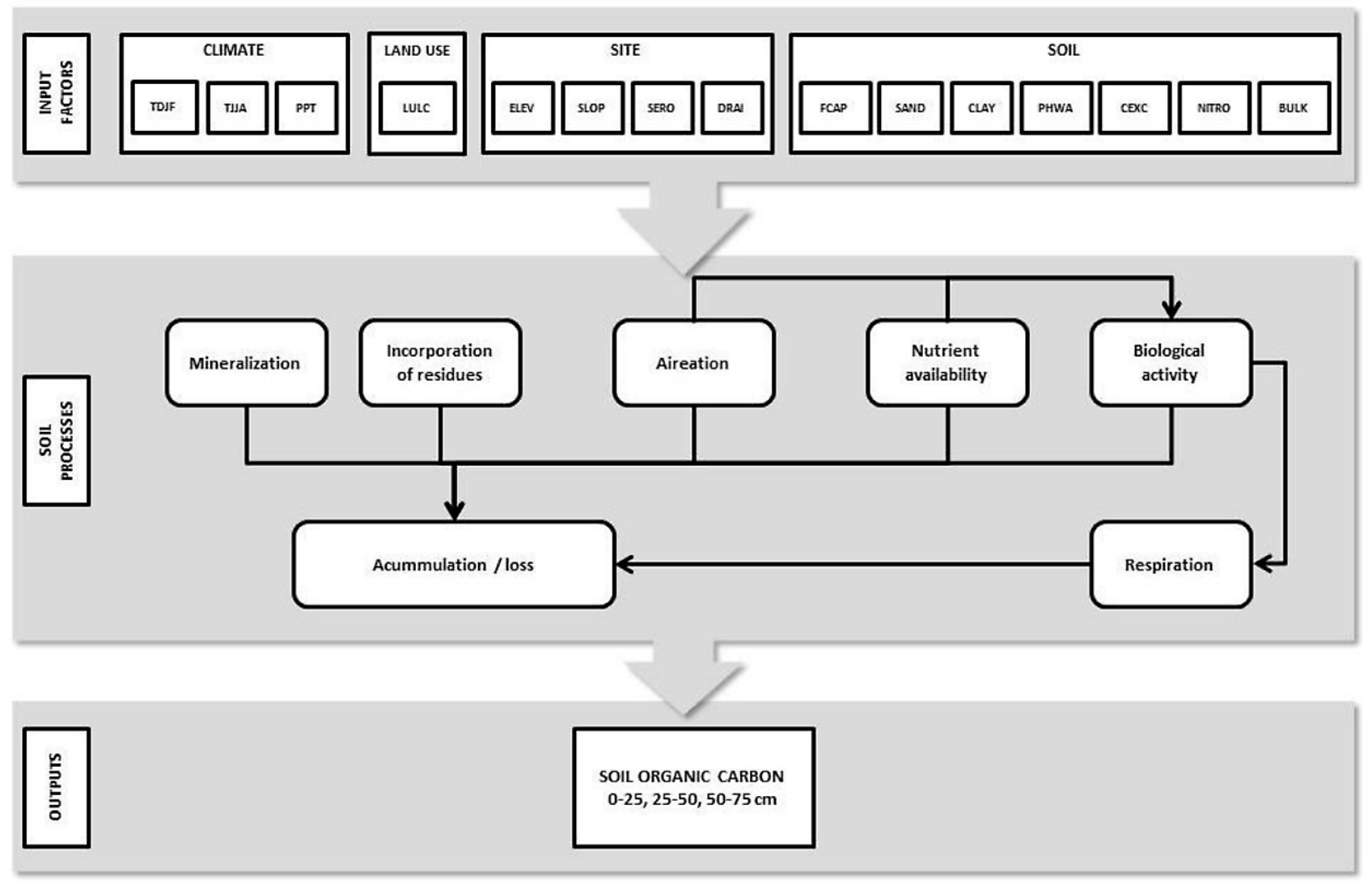

Fig. 2. General diagram of the CarboSOIL model: input factors. simulated soil processes and outputs. Input factor abbreviations are described in Table 1.

(meq/100 g), sand (\%), clay (\%), bulk density (g/cc), field capacity $(\mathrm{g} / 100 \mathrm{~g})$ and organic carbon content $(\%)$.

Soil profiles showed a range of depths; therefore, soil data (Table 1) were homogenized and re-sampled to standard soil depths for computing $(0-75,0-25,25-50$ and $50-75 \mathrm{~cm})$. In order to homogenize information from soil profiles, soil variables were re-coded and imported to the geo-referenced SDBm Plus Multilingual Soil Profile Database, which contains a large amount of descriptive and analytical data fields (De la Rosa et al., 2002). The SDBm Plus database incorporates a "control section" function, which allows determining the thickness of the layer to be analysed within the soil profile. This function calculates the weighted average value for each variable in standard control sections.

\subsection{Land use and land cover data}

Land use for the model application was obtained from the land use and land cover map of Andalusia (LULCMA) for 2007 at scale $1: 25000$ and minimum map unit 0.5 ha (Moreira, 2007). This digital spatial data set, obtained after the analysis of satellite images (Landsat TM, IRS/PAN and SPOT-5) and digital aerial photographs, is a result of the Coordination of Information on the Environment
(CORINE) programme, promoted by the European Commission in 1985 for the assessment of environmental quality in Europe. Within the CORINE programme, CORINE Land Cover (CLC) project provides consistent information on land cover and land cover changes across Europe. The LULCMA for 2007 provides an updated version of the original maps at scale $1: 100000$ and constitutes a more detailed and accurate database, both thematically and geometrically.

The standard CLC nomenclature includes 44 land cover classes, grouped in a three-level hierarchy. Land cover classes of LULCMA were reclassified into CLC nomenclature at level 3 (the most detailed level) according to the method described in Muñoz-Rojas et al. (2011) in order to apply the CarboSOIL model. Agricultural, natural and semi-natural areas and wetlands were selected composing a total of 14 land cover classes (Non-irrigated arable land, permanently irrigated land, vineyards, fruit trees and berry plantations, olive groves, complex cultivations patterns, agro-forestry areas, broad-leaved forests, coniferous forests, mixed forests, natural grasslands, sclerophyllous vegetation, transitional woodland/scrub and salt marshes). 


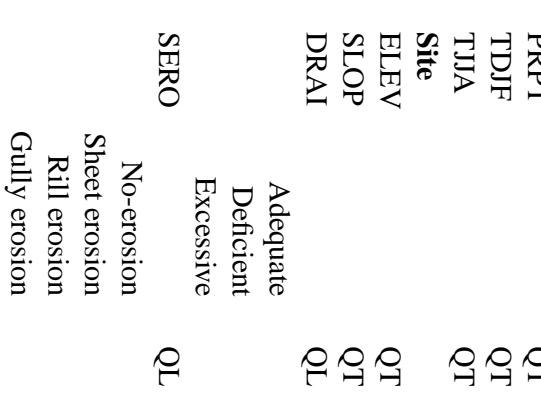

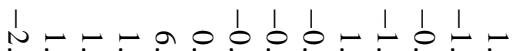

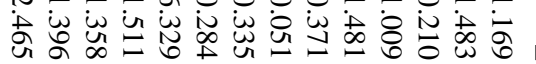

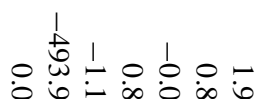
is 1

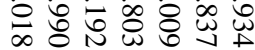
w

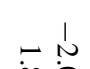

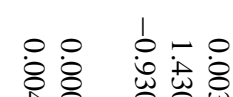

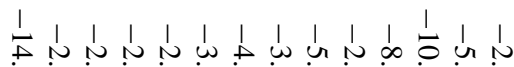
二 le

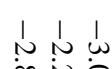

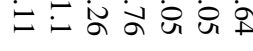
证定

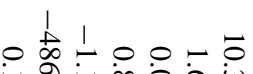

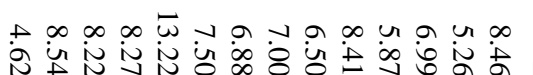

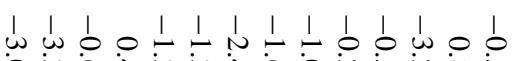

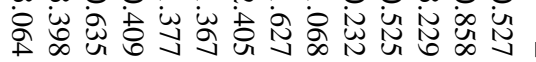

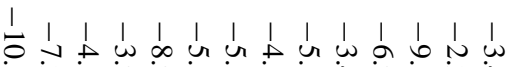

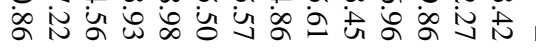

W N U U n

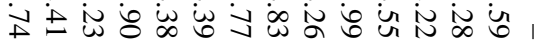

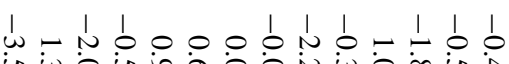

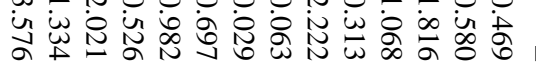

إن

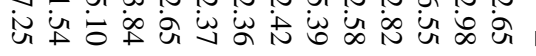

Now

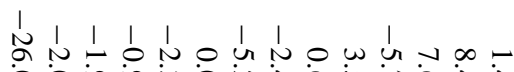

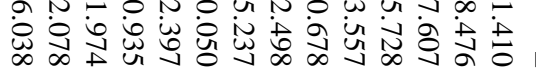

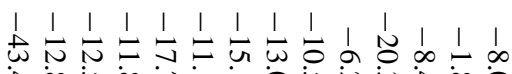

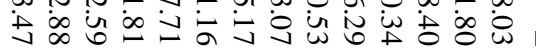

lom $\infty$ o

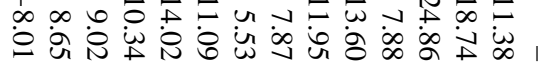

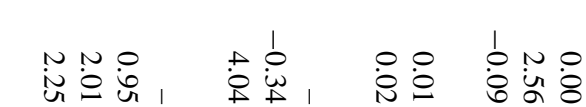

1

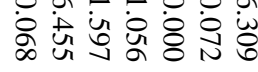

1 1 a $1-1,1]$

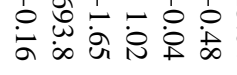

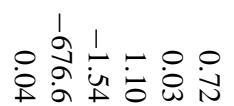
일

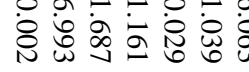
究卖京 岕斿 \&)

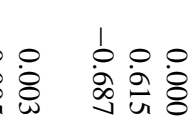
$+\frac{1}{2}$

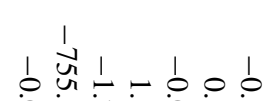

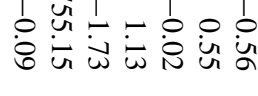
$\checkmark$ 崩

\section{$\frac{1}{2} 1$} $8 \%$

\section{b}

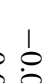

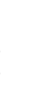

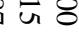

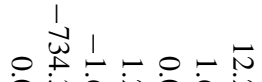

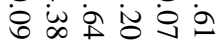

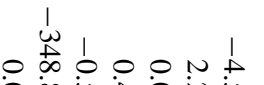

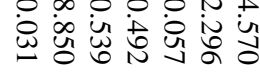

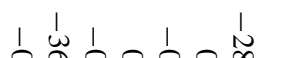

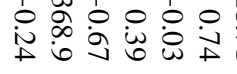

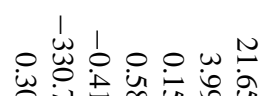

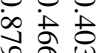

$+1$

10 $\stackrel{\circ}{\circ}$

$8 \dot{8}: 8$ \begin{tabular}{ll}
1 & 1 \\
1 & 1 \\
\hline & 0 \\
0 & 0 \\
0 & 0 \\
0 & 0
\end{tabular} 


\subsection{Calculation of soil organic $\mathrm{C}$ stocks and simulation process/prediction of soil organic carbon stocks}

To determine soil organic carbon contents (SOCCs) in current scenarios, the following equation was applied for each soil layer of the 1356 soil profiles:

$\mathrm{SOCC}=\mathrm{SOCP} \times \mathrm{BD} \times D \times(1-G)$,

where SOCC is soil organic carbon content $\left(\mathrm{Mg} \mathrm{ha}^{-1}\right)$, SOCP soil organic carbon percentage $\left(\mathrm{g} 100^{-1} \mathrm{~g}^{-1}\right)$, BD bulk density $\left(\mathrm{g} \mathrm{cm}^{-3}\right), D$ the thickness of the studied layer (cm) and $G$ the proportion in volume of coarse fragments. Similar approaches at different scales were used by Rodríguez-Murillo (2001) in peninsular Spain and by BoixFayos et al. (2009) in Murcia (SE Spain). Soil profiles were classified according to original soil profile descriptions, into 10 soil reference groups (IUSS Working Group WRB, 2006): Arenosols, Calcisols, Cambisols, Fluvisols, Leptosols, Luvisols, Planosols, Regosols, Solonchaks and Vertisols, and 7 land use types (following CLC nomenclature at level 2: "Arable land", "Permanent crops", "Heterogeneous agricultural areas", "Forest", "Scrub and/or vegetation associations", "Open spaces with little or no vegetation", and "Maritime wetlands"). Subsequently, soil profiles were grouped into association of soil and land use units (landscape units). These landscape units are defined by one soil reference group and one aggregated land cover type at level 2 of CLC nomenclature. To predict SOCC in climate change scenarios at different soil depth, the CarboSOIL model (CarboSOIL25, CarboSOIL50, CarboSOIL75 and CarboSOILTOTAL) was run under the different climate change scenarios for each soil profile. Data analyses were performed using ArcGIS v.10 software (ESRI, 2011) and SPSS (2009).

To determine SOC stocks and to obtain soil carbon maps in present and future scenarios, the study area was divided into landscape units using a topological intersection of the LULCMA for 2007 and the soil map of Andalusia (CSICIARA, 1989) at scale 1:400 000. The overlay of both maps resulted in a new spatial data set composed of 85492 new polygons. Mean values of SOC contents $\left(\mathrm{Mgha}^{-1}\right)$ of the different landscape units, previously determined for each climate change scenario, were assigned to all the new polygons. SOC stocks were determined by multiplying SOC content mean values by the area occupied by the landscape unit in the overlay map.

\subsection{CarboSOIL model evaluation}

Correlations between modelled baseline scenarios (current scenario) and measured SOC pools from soil databases were determined. The Kolmogorov-Smirnov test was used to test whether differences between observed and predicted SOC contents were significant. Analyses were performed with SPSS software for each submodel (CarboSOIL25, CarboSOIL50, CarboSOIL75 and CarboSOILTOTAL).
To assess the causal relationship between climate and land use variables, and SOC dynamics, an evaluation of the CarboSOIL model was carried out testing the model for annual precipitation, mean summer temperature and mean winter temperature for each land use type. The model was applied modifying these climate variables (using minimum and maximum values, Table 3 ), whereas the rest of variables were set with their average values.

\section{Results}

\subsection{Model performance and validation}

Measured SOC contents were well correlated with predicted values obtained with CarboSOIL application under the current scenario (baseline scenarios), with $R$ Spearman values ranging between 0.8840 and 0.9912 for the different submodels (Table 4). Model performance proved to be more accurate for different sections (CarboSOIL25, CarboSOIL50 and CarboSOIL75), yet CarboSOILTOTAL showed a satisfactory ability to predict SOC contents.

The results of the model evaluation showed that the CarboSOIL model was sensitive to climate parameters in all land uses (Fig. 3). In particular, modelling under different temperature regimes showed that SOC increases with winter temperature in all sections of the soil profile and decreases with summer temperature in the total profile and the upper layers (up to $50 \mathrm{~cm}$ ). However, in the deeper layer $(50-75 \mathrm{~cm}$ ) the opposite process occurred, and SOC enlarged with summer temperatures.

\subsection{Prediction of SOC stocks and projected changes in response to climate change}

\subsubsection{SOC stocks under SRES scenarios and GCM models at different soil depth}

Total SOC stocks predicted by application of CarboSOIL for the periods 2040, 2070 and 2100 under SRES scenarios and GCMs are shown in Fig. 4. In the upper $25 \mathrm{~cm}$, SOC stocks ranged between 228.5 and $234.5 \mathrm{Tg}$ in 2040, 229.1 and $235.1 \mathrm{Tg}$ in 2070 , and 226.5 and $234.2 \mathrm{Tg}$ in 2100 . In the soil section between $25 \mathrm{~cm}$ and $50 \mathrm{~cm}$, the $S O C$ pool varied from 151.5 to $154.9 \mathrm{Tg}$ in $2040,149.9$ to $153.5 \mathrm{Tg}$ in 2070 , and 146.7 to $153.3 \mathrm{Tg}$ in 2100 . SOC stocks in the deeper soil section $(50-75 \mathrm{~cm})$ ranged between 129.0 and $130.0 \mathrm{Tg}$ in 2040, 129.3 and $131.7 \mathrm{Tg}$ in 2070, and 130.9 and $134.7 \mathrm{Tg}$ in 2100. Finally, the projected SOC stocks in the total soil profile (0-75) varied from 378.7 to $401.7 \mathrm{Tg}$ in 2040 , from 371.6 to 395.5 in $2070 \mathrm{Tg}$, and 350.2 to $392.3 \mathrm{Tg}$ in 2100 .

Figure 5 displays the spatial distribution of changes in SOC contents for the different climate change scenarios and the different periods (2040, 2070 and 2100) considered in this research. In general the northwestern and the eastern areas of Andalusia would be the most affected by climate 
change, with SOC losses above $4 \mathrm{Mg} \mathrm{ha}^{-1}$ in 2040 and up to $8 \mathrm{Mg} \mathrm{ha}^{-1}$ in 2070 and 2100.

\subsubsection{Changes in SOC stocks for each soil type and land use at different soil depth}

Future changes of SOC stocks predicted by CarboSOIL for different soil types and soil depths are shown in Fig. 6. Although there is an overall trend in all soil types towards decreasing of SOC stocks in the upper soil sections (0-25 and $25-50$ ), predicted SOC stocks tend to increase in the deeper soil section $(0-75)$ in future climate scenarios. In the upper $25 \mathrm{~cm}$, the predictions showed that SOC stocks decrease in most of the soil types under A1B, A2 and B1 scenarios, in particular in Arenosols, Planosols and Solonchaks. In Arenosols, SOC contents would decrease by $2.3-2.7 \%$ in $2040,2.3-3 \%$ in 2070 and up to $3.6 \%$ in 2100 . In Solonchaks, rates of change in SOC stocks in the upper $25 \mathrm{~cm}$ are similar to those predicted for Arenosols. These soil types are common in arid areas and cover 478.8 ha (Arenosols) and 652.7 ha (Solonchaks), which represents a small portion of the study area (1.0 and $0.9 \%$ respectively) and shows low organic $\mathrm{C}$ contents (Table 5). Larger decreases were projected in Planosols, in which SOC would decrease by $4.3-4.6 \%$ in $2040,4.4-5.4 \%$ in 2070 and $4.7-6.3 \%$ in 2100 . In the soil section ranging from 25 to $50 \mathrm{~cm}$, major decreases of SOC stocks were predicted in the same soil types (Arenosols, Planosols and Solonchaks) in addition to Cambisols, with SOC declines up to $5.4 \%$ in 2100 for the A2 scenario.

In general, SOC stocks would increase in the deeper layer $(50-75 \mathrm{~cm})$ of most soil types, and these rates would be particularly large in Cambisols, the most predominant group in the study area (Table 5), with predictions of SOC accumulation rates between $5.7 \%$ and $5.9 \%$ in $\mathrm{A} 1 \mathrm{~B}$ and $\mathrm{A} 2$ scenarios respectively. Opposite, SOC stocks decline in the deeper soil section of Planosols and Solonchaks. A similar pattern was found in SOC stocks under projected scenarios for the different land uses, with SOC declining in the upper layers and increasing in the deeper section of the soil profile.

Among agricultural uses, "permanent crops" would be the most affected by climate change with SOC decreases between 3.1 and $3.8 \%$, in 2040, 3.2 and $4.4 \%$ in 2070, and up to $5.7 \%$ in 2100 in the upper layer $(0-25 \mathrm{~cm})$ (Fig. 7). In the soil section from 50 to 75 , SOC would decline up to $6.2 \%$ (A2 scenario), but projections in the deeper layer $(50-75 \mathrm{~cm})$ indicated an increase of 5-12\% in the SOC contents of this agricultural type. In natural areas CarboSOIL predicted important losses of SOC contents in the upper layers of the soil profile of "open spaces with little or no vegetation". In this land use type, $9.3 \%$ of the SOC would be lost under the A2 scenario by 2100 in the $0-25 \mathrm{~cm}$ soil section and $28.6 \%$ in the $25-50 \mathrm{~cm}$ soil section. However, positive rates of change were predicted in the $50-75 \mathrm{~cm}$, with SOC increases ranging from 10.2 to $16.3 \%$ in 2100. Minor decreases of SOC were observed in "shrubs" in the upper layers, with average val- ues of $2.4 \%$ by 2040 and 2070 and $2.8 \%$ by 2100 in the 0 $25 \mathrm{~cm}$ section, and $0.4 \%$ by $2014,1.2 \%$ by 2070 and $2.3 \%$ in the $25-50 \mathrm{~cm}$ section. Nonetheless, it is noteworthy that the model predicted large increments of SOC contents in the $50-75 \mathrm{~cm}$ section of the soil profile, in particular by 2100 with positive changes of SOC stocks ranging from 11.7 to $13.1 \%$.

\section{Discussion}

\subsection{Predicted future SOC stocks under climate change scenarios}

This study applies four submodels of a SOC model (CarboSOIL) in order to quantify SOC at different soil depths. The model is driven by BCCR-BCM2, CNRMCM3 and ECHAM5 climate predictions, with three IPCC forcing scenarios (A1B, A2 and B2) to predict the effects of climate change on SOC contents and sequestration. The CarboSOIL model has proved its ability to predict SOC stocks at different soil depths $(0-25,25-50$ and $50-75 \mathrm{~cm})$ in global change scenarios. Our research provides the first estimates of SOC contents and stocks in southern Spain in future scenarios and allows analysing $\mathrm{C}$ sequestration trends associated with climate change. Overall, our results suggest that climate change will have a negative impact on SOC contents in the upper layers of the soil section.

According to our findings, climate factors have a considerable effect on SOC contents. In the top soil layers, SOC stocks decrease when diminishing rainfall, opposite to the increases in deeper layers. Although climate change scenarios predict a decrease in annual precipitation, more intensive rainfall events are expected. These events are likely to change soil structure and soil quality, particularly in upper layers, which together with SOC depletion makes the soil more susceptible to erosion processes (Cerdà, 1988; Christensen et al., 2011; Muñoz-Rojas et al. 2012b).

Increasing summer temperatures will affect the SOC pools up to $50 \mathrm{~cm}$, with a consequent depletion of this pool, mainly in sensitive land areas such as salt marshes and fruit trees and berry plantations. On the other hand, the sensitivity analysis suggests that winter temperatures are desirable for increasing SOC contents. It has been reported that increasing temperatures will accelerate $\mathrm{C}$ decomposition (above photosynthesis rates) due to the rise of temperatures (Zhang et al., 2005). This effect will be stresses in managed soils and, consequently, direct climate impacts on croplands and grasslands soils will tend to decrease SOC stocks all over Europe (Smith et al., 2005). Our results suggest that the effects of temperature are different along the soil profile decreasing with depth, which is in accordance with previous studies in Mediterranean areas (Albaladejo et al., 2013). These differences might be explained by changes of properties in soil organic carbon compounds or even enzymatic processes in 


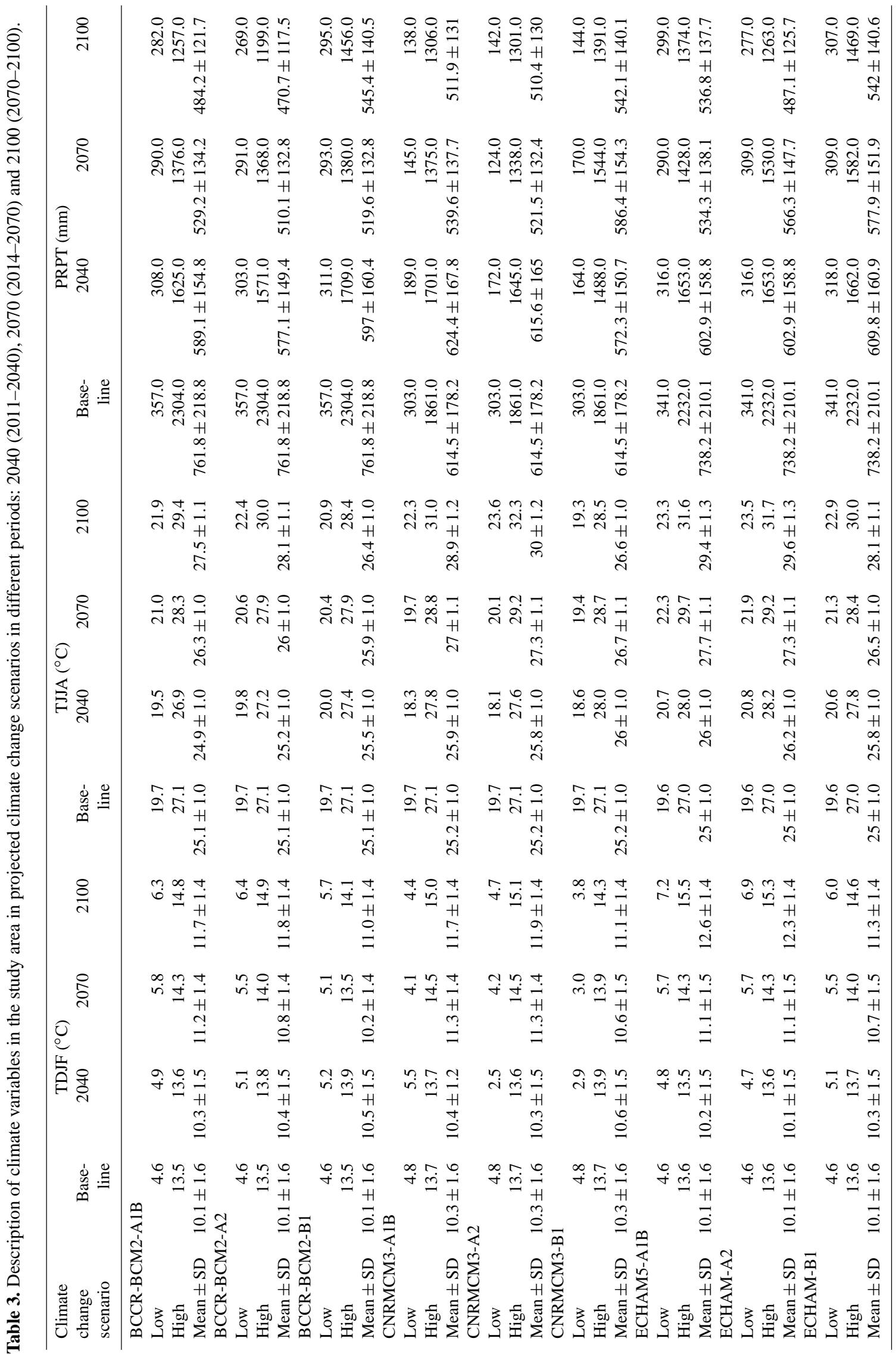


Table 4. Measured and modelled soil organic C (SOC) content $\left(\mathrm{Mg} \mathrm{ha}^{-1}\right)$ under current scenario (baseline scenarios according to BCCRBCM2, CNRMCM3 and ECHAM5), and results of the Kolmogorov-Smirnov test. All correlations are significant at the 0.01 level.

\begin{tabular}{|c|c|c|c|c|c|c|c|c|c|c|c|c|c|}
\hline \multirow{2}{*}{$\begin{array}{l}\text { Soil } \\
\text { depth } \\
\text { (cm) }\end{array}$} & \multirow[t]{2}{*}{$N$} & \multicolumn{2}{|c|}{ Measured SOC } & \multicolumn{3}{|c|}{$\begin{array}{l}\text { BCCR-BCM2 } \\
\text { Modelled SOC }\end{array}$} & \multicolumn{3}{|c|}{$\begin{array}{l}\text { CNRMCM3 } \\
\text { Modelled SOC }\end{array}$} & \multicolumn{3}{|c|}{$\begin{array}{c}\text { ECHAM5 } \\
\text { Modelled SOC }\end{array}$} & \multirow{2}{*}{$\begin{array}{c}\text { Kolmogorov- } \\
\text { Smirnov } \\
\text { test }(p)\end{array}$} \\
\hline & & Mean & SD & Mean & SD & $R$ & Mean & SD & $R$ & Mean & $\mathrm{SD}$ & $R$ & \\
\hline $0-25$ & 1504 & 30.51 & 28.11 & 31.36 & 29.93 & 0.9889 & 31.70 & 26.89 & 0.9892 & 31.48 & 26.90 & 0.9892 & $<0.01$ \\
\hline $25-50$ & 1033 & 19.66 & 19.18 & 19.82 & 18.60 & 0.9898 & 19.88 & 18.60 & 0.9898 & 19.87 & 18.59 & 0.9898 & $<0.01$ \\
\hline $50-75$ & 600 & 15.65 & 14.67 & 15.87 & 14.31 & 0.9912 & 15.92 & 14.31 & 0.9912 & 15.88 & 14.31 & 0.9912 & $<0.01$ \\
\hline $0-75$ & 1504 & 51.25 & 47.55 & 54.48 & 38.82 & 0.8840 & 52.51 & 38.66 & 0.8850 & 54.47 & 38.88 & 0.8840 & $<0.01$ \\
\hline
\end{tabular}
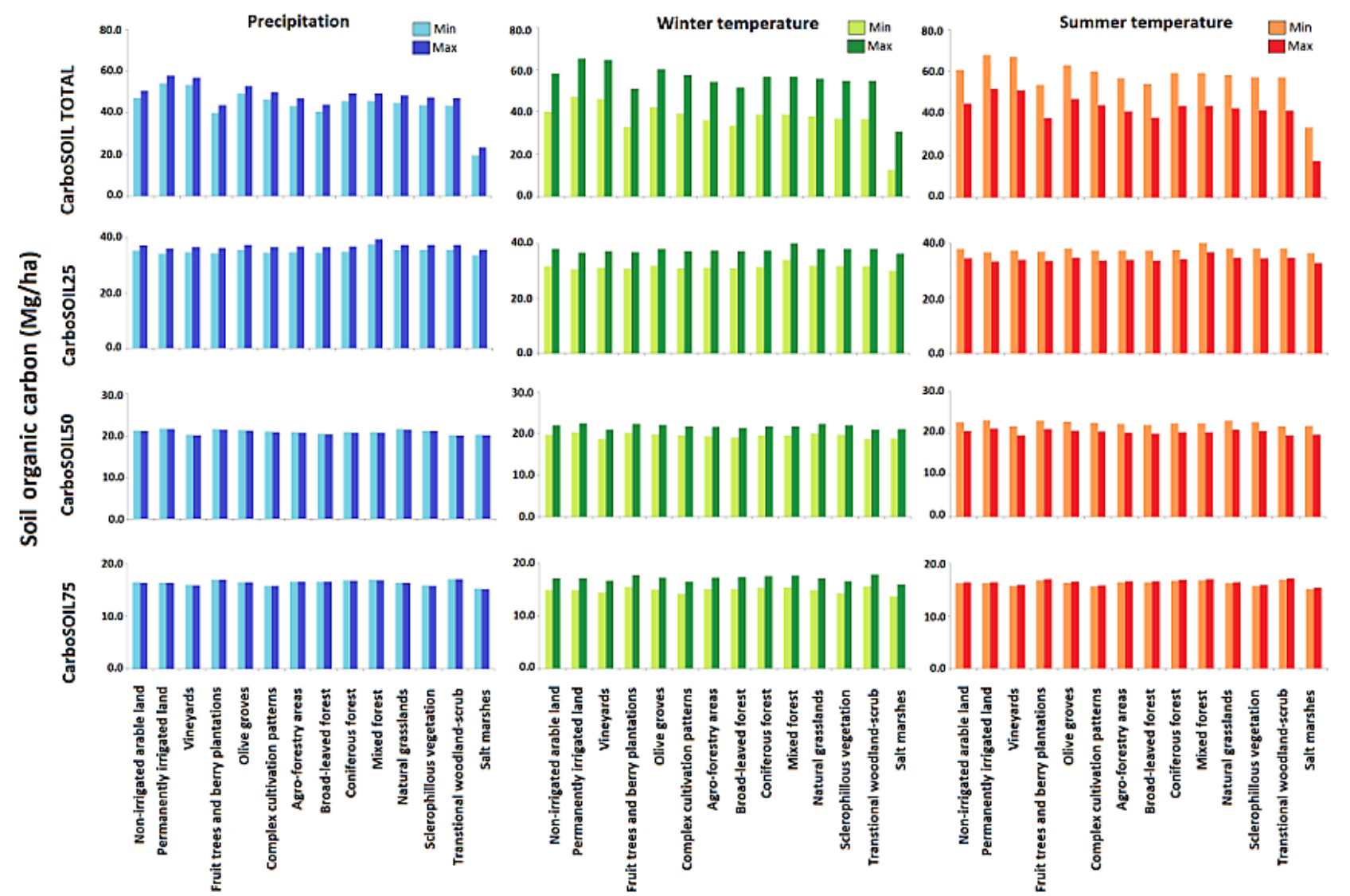

Fig. 3. CarboSOIL model evaluation for climate variables (annual precipitation, mean winter temperature and mean summer temperature) at different soil depths: 0-25 (CarboSOIL25), 25-50 (CarboSOIL50), 50-75 (CarboSOIL75) and 0-75 cm (CarboSOILTOTAL).

different horizons. Although temperature clearly affects decomposition of a labile SOC fraction, a significant portion of SOC is influenced by other environmental factors (Davidson and Janssens, 2006).

Another important factor to consider in the SOC distribution along the vertical section of the soil profile is the root allocation, which varies for different vegetation types (Jobbágy and Jackson, 2000; Yang et al., 2012). In the deeper layers of "shrubs", the model projected considerable increments in SOC stocks, which might be explained by the growth in depth of the vegetation roots of new species adapted to arid conditions of a future climate. Also, areas as "open spaces" will undertake important declines of SOC stocks in the 025 and the $25-50 \mathrm{~cm}$ sections of the soil profile. These areas are particularly vulnerable since are usually burnt areas or areas under erosive processes (Muñoz-Rojas et al., 2011). An increase on the occurrence and the intensity of forest fires is predicted in future climate scenarios, which might largely affect soil organic carbon quality and dynamics (Martín et al., 2012). However, in contrast to other land use types, the CarboSOIL model predicted minor losses of SOC stocks in 


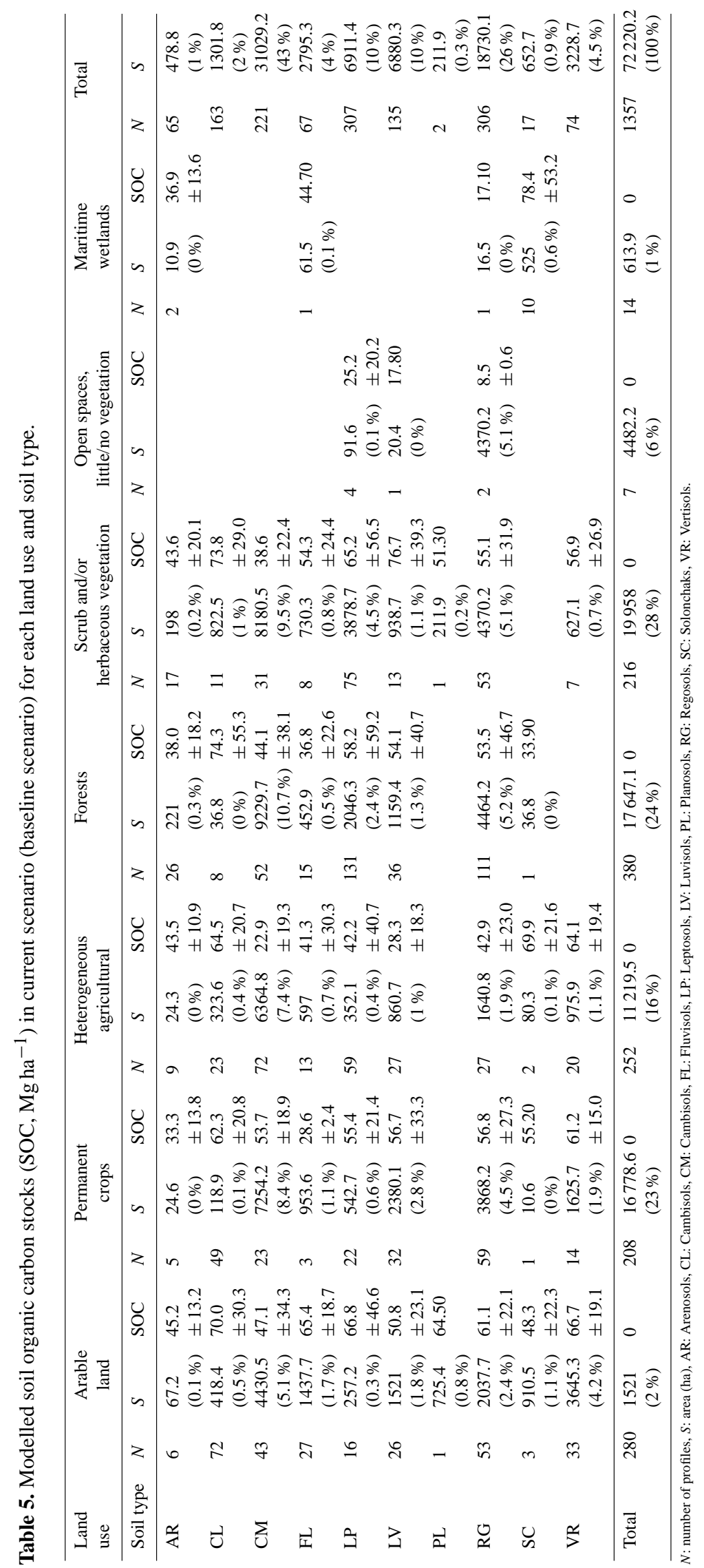



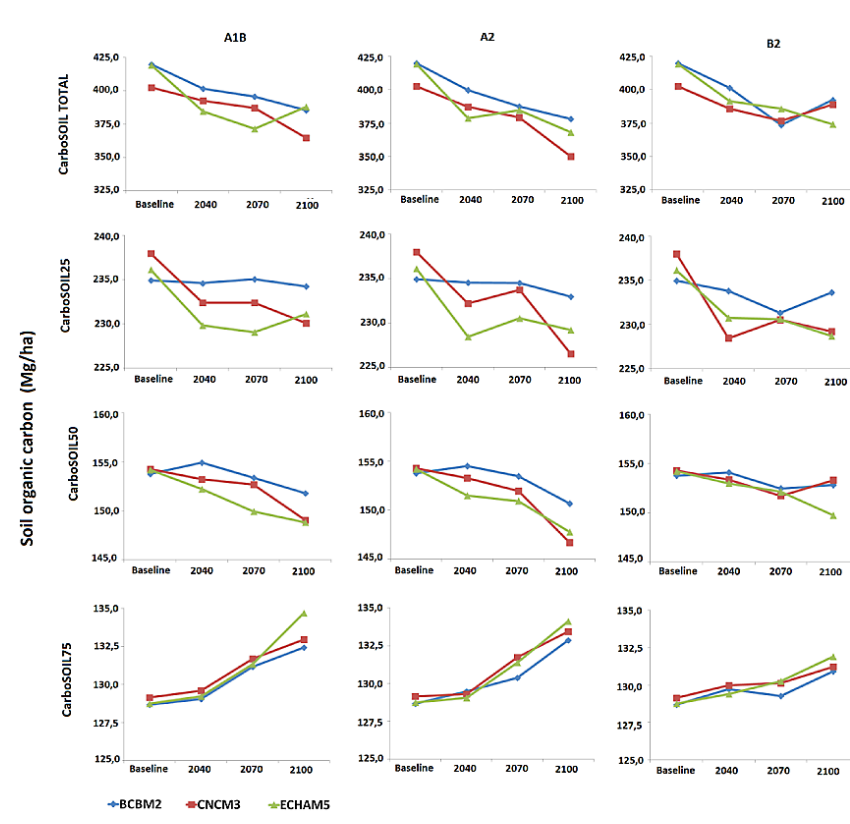

Fig. 4. Soil organic C stocks in climate change scenarios for each GCM and SRES in different periods (2040, 2070 and 2100) at different soil depths: 0-25 (CarboSOIL25), 25-50 (CarboSOIL50), 50-75 (CarboSOIL75) and 0-75 cm (CarboSOILTOTAL).

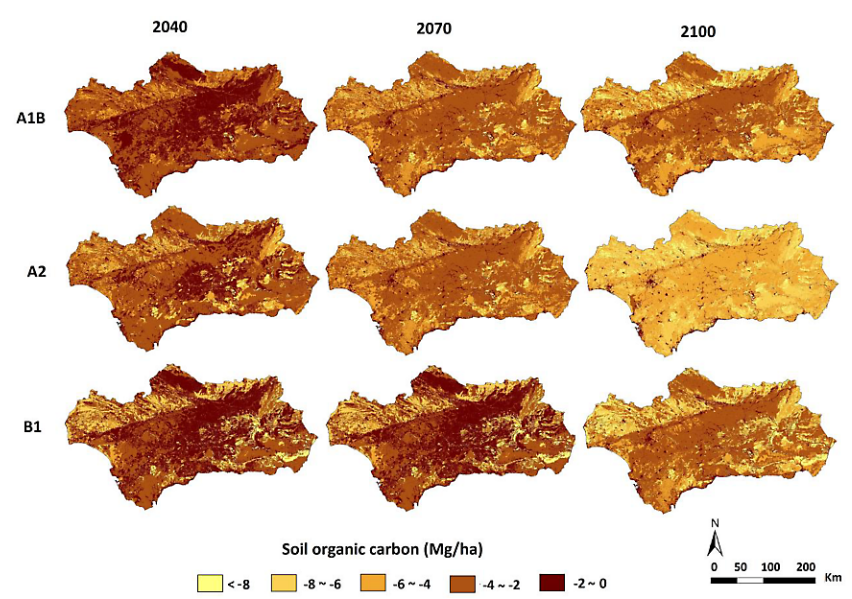

Fig. 5. Spatial distribution of changes in soil organic carbon content $\left(\mathrm{Mg} \mathrm{ha}^{-1}\right)$ in Andalusia (southern Spain) for different SRES scenarios and different periods $(2040,2070,2100)$.

"forests", which can be explained by a higher relative aboveground allocation.

Among the agricultural areas, the upper layers of "permanent crops" will be largely affected, in agreement with previous studies that reported decreases of SOC stocks of vineyards in Italy in the next decades (Francaviglia et al., 2012). The land use type "permanent crops" includes olive groves, vineyards and sensitive crops such as fruit trees and berry plantations and covers approximately $23 \%$ of the total

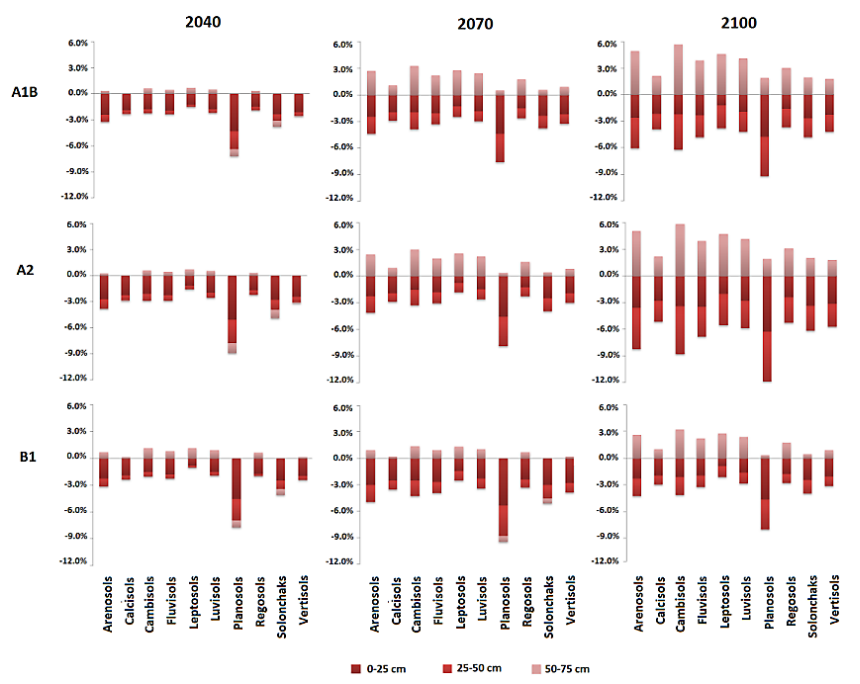

Fig. 6. Soil organic $C$ stocks in climate change SRES scenarios in different periods $(2040,2070$ and 2100) for each soil type at different soil depths $(0-25,25-50,50-75 \mathrm{~cm})$.

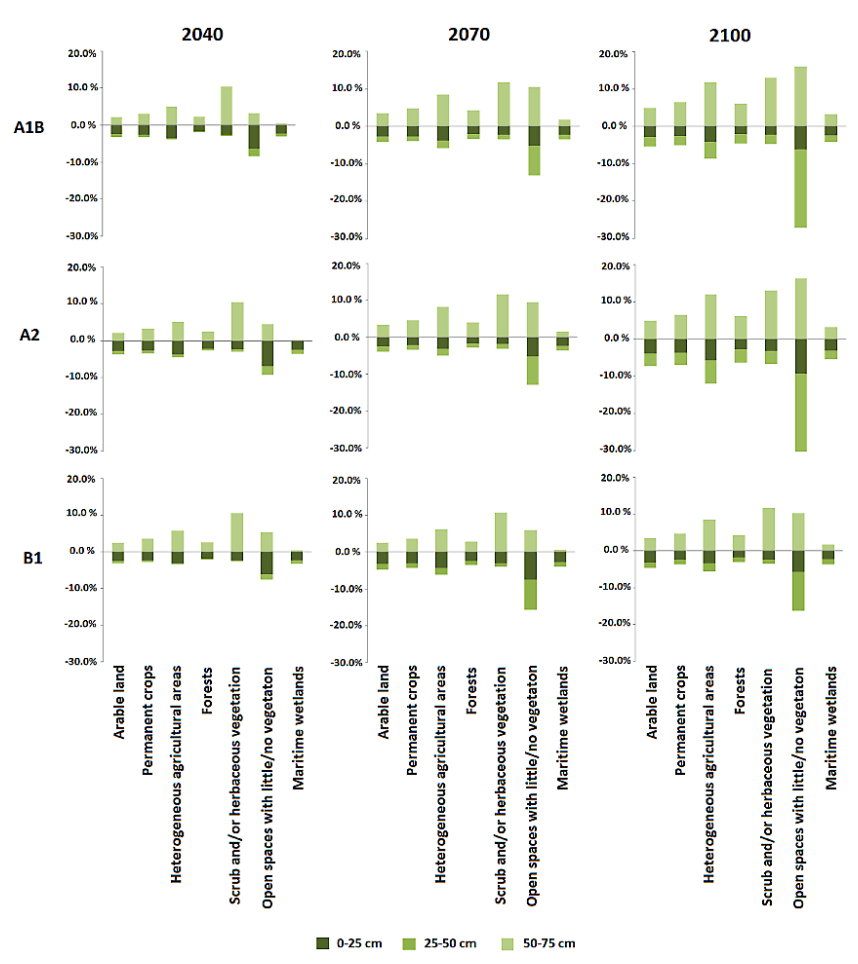

Fig. 7. Soil organic $C$ stocks in climate change SRES scenarios in different periods $(2040,2070$ and 2100) for each land use at different soil depths $(0-25,25-50,50-75 \mathrm{~cm})$.

area of Andalusia (Table 5). Therefore management practices should be considered to avoid SOC losses in these areas.

Despite the diversity of SOC contents associated with different climate change scenarios, our results show an evident decrease of SOC in southern Spain. In the total soil profile 
(first $75 \mathrm{~cm}$ ), SOC changes between 2000 and 2100 vary from $-3.4 \%$ in CNRMCM3-B1 to $-13.0 \%$ in CNRMCM3A2. Our results are generally in agreement with the works of Mondini et al. (2012), Smith et al. (2005), and Wan et al. (2011), which applied RothC model and projected a decrease of SOC during the 21st century. Absolute values cannot be directly compared due to the differences in the soil sections, but percentage change can be contrasted. Smith et al. (2005) predicted SOC changes between $-10 \%$ and $-14 \%$ of the 1990 mean SOC stock of European croplands, and between -6 and $-10 \%$ of the 1990 mean SOC stock of European grasslands. Wan et al. (2011) reported a percentage decrease of $5.5 \%, 12 \%$ and $15 \%$ in SOC by the years 2020,2050 and 2080, respectively, in northern China. In their study, Mondani et al. (2012) projected SOC losses between 2001 and 2100 with values ranging from $-4.4 \%$ in the PCM-B1 scenario to $-11.5 \%$ in the CGM2-A1F1 scenario, consistent with our results. Álvaro-Fuentes and Paustian (2011) and ÁlvaroFuentes et al. (2012) predicted increases in SOC contents of Spanish agroecosystems under future climate change scenarios, which differ from our simulations. However, in both studies they applied Century SOC, which accounts for SOC stocks only in the upper $30 \mathrm{~cm}$.

\subsection{Uncertainties and limitations}

Changes in land use and management are expected in the future decades at global, regional and local scales with a consequent effect on soil carbon contents, in particular in Mediterranean areas (Barberá et al., 2012; García-Orenes et al., 2009). However, in our projections land use remains invariable between the 2000-2100 periods. The purpose of this study is to apply and test CarboSOIL in climate change scenarios and to assess SOC changes in response to climate change. Therefore, land uses are considered constant over the simulation period.

Results obtained from application of simulation models in climate change scenarios are related to different sources of uncertainty, associated mainly with the model imprecision and the climate scenarios. CarboSOIL is an empirical model based on regression techniques. These techniques offer a high predictive ability and comprise multiple advantages such as ease in application and simplicity of interpretation (Hastie et al., 2001; Oliveira et al., 2012). Although these statistical procedures are not able to explain complex mechanisms within the soil system, such as process-based or mechanistic models, empirical models are useful tools to identify different drivers of SOC dynamics and to perform projections of SOC stocks (Viaud et al., 2010). CarboSOIL, as an empirical model, does not require a high quantity of detailed data, and the data needed are frequently available at national, regional and even plot scale. Global warming and increased $\mathrm{CO}_{2}$ concentrations in the atmosphere in a future climate scenario are predicted to raise the net ecosystem productivity (NEP). The increase in NEP, which is the organic carbon in an ecosystem available for storage, could lead to a larger input of organic matter in the soil (Lovett et al., 2006). CarboSOIL does not consider these factors, which could have considerable impacts on predicted SOC contents in future scenarios. However, it is difficult to predict the $\mathrm{CO}_{2}$ fertilization effect, in particular in a long-term period, because the $\mathrm{CO}_{2}$ levels might reach saturation, and other factors such as water deficit could play an important role (Fatichi and Leuzinger, 2013). Furthermore, different processes take place along the soil profile, and the relationship between the SOC decomposition and external organic carbon (plant litter, root exudates, etc.), microbial activity or environmental variables at different soil depth is difficult to model (Zhang et al., 2013).

Nevertheless the evaluation of CarboSOIL evidences the ability of the model to identify cause-effect relationships with climate factors. The CarboSOIL model has proved to be consistent, and measured values were well correlated with the modelled values. Among others, one of the main advantages of CarboSOIL is that the model does not require a high quantity of detailed data, and the data needed are mostly available at national, regional and even plot scale. Designed as a GIS tool, the model has shown a high capacity to quantify and understand soil carbon distribution for different land use and soil types.

A range of model projections is considered in this study. We obtain different results of SOC contents associated with different climate predictions, which highlight the uncertainty in future climate scenarios. In climate projections, uncertainties can be related to emissions, climatic drivers (e.g. carbon cycle), climate sensitivity and adaptive capacity, among others (Van Vuuren et al., 2011).

In areas of complex topography, like the Mediterranean region, application of GCMs might result in considerable biases in the prediction of precipitation and temperature (Giorgi and Lionello, 2008). In particular precipitation involves local processes of larger complexity than temperature, and projections are usually less robust than those for temperature. Regionalized climate data used here contribute to a better adjustment of climate change scenarios to the physiographic environment of the study area. The climate system suffers variations on different timescales. In this work we consider time periods of 30 years, given that this time slice has been traditionally considered (Christensen et al., 2011; IPCC, 2007) to assess climate factors with some confidence.

\section{Conclusions}

In our study, we applied CarboSOIL in climate change scenarios to determine SOC changes in 2040, 2070 and 2100 in a Mediterranean region (southern Spain). The model has proved to be consistent, and measured values were well correlated with the modelled values. Linking the CarboSOIL model to detailed spatial databases allows 
measuring regional SOC stocks and sequestration potential. This research provides SOC content and stock estimates in southern Spain in future climate scenarios, assessing $\mathrm{C}$ sequestration trends associated with climate change. Our results showed that climate change will have a negative impact on SOC contents in the upper layers of the soil section (0-25 and $25-50 \mathrm{~cm}$ ), in particular in soils as Arenosols, Planosols and Solonchaks. The model predicted declines of SOC stocks in the $0-25$ and $25-50 \mathrm{~cm}$ soil sections of "permanent crops" among agricultural areas and "scrubs" among natural areas.

The methodology can be easily applied to other Mediterranean areas with available data on soil, site, land use and climate factors. Additionally, coupling detailed spatial databases with the CarboSOIL model allows measuring regional SOC stocks and sequestration potential. This study might support decision-making in land management and climate adaptation strategies in Mediterranean regions.

Acknowledgements. The authors wish to thank the European Geosciences Union for inviting M. Muñoz-Rojas, recipient of the EGU Young Scientists Outstanding Poster Paper Award 2012, to submit this paper free of publication charges. This research has been partly funded by the Spanish Ministry of Economy, Innovation and Science (Research Project 851238) and Regional Ministry of Environment (Research Project 0501/0268) of the Andalusian Government.

Edited by: T. Laurila

\section{References}

Aguilera, E., Lassaletta, L., Gattinger, A., and Gimeno, B. S.: Managing soil carbon for climate change mitigation and adaptation in Mediterranean cropping systems: A meta-analysis, Agr. Ecosyst. Environ., 168, 25-36, 2013.

Albaladejo, J., Ortiz, R., Garcia-Franco, N., Ruiz Navarro, A., Almagro, M., Garcia Pintado, J., and Martínez-Mena, M.: Land use and climate change impacts on soil organic carbon stocks in semi-arid Spain, J. Soils Sediments, 13, 265-277, 2013.

Álvaro-Fuentes, J. and Paustian, K.: Potential soil carbon sequestration in a semiarid Mediterranean agroecosystem under climate change: Quantifying management and climate effects, Plant Soil, 338, 261-272, 2011.

Álvaro-Fuentes, J., Easter, M., and Paustian, K.: Climate change effects on organic carbon storage in agricultural soils of northeastern Spain, Agr. Ecosyst. Environ., 155, 87-94, 2012.

Anaya-Romero, M., Pino, R., Moreira, J. M., Muñoz-Rojas, M., and De la Rosa, D.: Analysis of soil capability versus land use change by using CORINE land cover and MicroLEIS, Int. Agrophys., 4, 395-398, 2011

Anaya-Romero, M., Muñoz-Rojas, M., Pino, R., Jordán, A., Zavala, L. M., and De la Rosa, D.: Carbosoil, a land evaluation model for soil carbon accounting, EGU General Assembly, Vienna, Austria, 22-27 April, EGU2012-7227, 2012.

Barberá, V., Poma, L., Gristina, L., Novara, A., and Egli, M.: Longterm cropping systems and tillage management effects on soil organic carbon stock and steady state level of $\mathrm{C}$ sequestration rates in a semiarid environment, Land Degrad. Develop., 23, 8291, 2012.

Batjes, N. H.: Total carbon and nitrogen in the soils of the world, European J. Soil Sci., 47, 151-156, 1996.

Batjes, N. H.: Soil carbon stocks of Jordan and projected changes upon improved management of croplands, Geoderma, 132, 3-4, 2006.

Bermejo, D., Cáceres, F., Moreira, J. M., Montes, J. E., Sánchez, S., Laguna, D., Caballo, A., Anaya Romero, M., and Asensio, B.: Medio siglo de cambios en la evolución de usos del suelo en Andalucía 1956-2007. Sevilla, Consejería de Medio Ambiente, Junta de Andalucía, 2011.

Boix-Fayos, C., de Vente, J., Albaladejo, J., and Martínez-Mena, M.: Soil carbon erosion and stock as affected by land use changes at the catchment scale in Mediterranean ecosystems, Agr. Ecosyst. Environ., 133, 75-85, 2009.

Cerdà, A.: Relationships between climate and soil hydrological and erosional characteristics along climatic gradients in Mediterranean limestone areas, Geomorphology, 25, 123-134, 1998.

Chiesi, M., Moriondo, M., Maselli, F., Gardin, L., Fibbi, L., Bindi, M., and Running, S. W.: Simulation of Mediterranean forest carbon pools under expected environmental scenarios, Can. J. Forest Res., 40, 5, 850-860, 2010.

Christensen, O. B., Goodess, C. M., Harris, I., and Watkiss, P.: European and Global Climate Change Projections: Discussion of Climate Change Model Outputs, Scenarios and Uncertainty in the EC RTD ClimateCost Project, in: The Climate Cost Project, Final Report, Volume 1, Europe, Sweden, Stockholm Environment Institute, 2011.

Coleman, K. and Jenkinson, D. S.: ROTHC-26.3. A model for the turnover of carbon in soil, in: Evaluation of soil organic matter models using existing, long-term datasets, Heidelberg, NATO ASI Series I, Vol. 38, Springer-Verlag, 237-246, 1999

CSIC-IARA: Mapa de suelos de Andalucía, Instituto Andaluz de la Reforma Agraria (Junta de Andalucía), Sevilla, Consejo Superior de Investigaciones Científicas, Madrid, 1989.

Davidson, E. A. and Janssens, I. A.: Temperature sensitivity of soil carbon decomposition and feedbacks to climate change, Nature, 440, 165-173, 2006.

De la Rosa, D., Mayol, F., Moreno, F., Cabrera, F., Diaz-Pereira, E., and Antoine, J.: A multilingual soil profile database (SDBm Plus) as an essential part of land resources information systems, Environ. Modell. Softw., 17, 721-730, 2002.

De la Rosa, D., Mayol, F., Moreno, F., Cabrera, F., Diaz-Pereira, E., and Fernández, M.: A Land Evaluation Decision support System (MicroLEIS DSS) for Agricultural Soil Protection, Environ. Modell. Softw., 19, 929-942, 2004.

ESRI: ArcGIS Desktop: Release 10. Redlands, CA, Environmental Systems Research Institute, 2011.

Falloon, P. and Smith, P.: Accounting for changes in soil carbon under the Kyoto Protocol: need for improved long-term data sets to reduce uncertainty in model projections, Soil Use Manage., 19, 265-269, 2003.

Falloon, P. D., Smith, P., Smith, J. U., Szabó, J., Coleman, K., and Marshall, S.: Regional estimates of carbon sequestration potential: linking the Rothamsted Carbon Model to GIS databases, Biol. Fert. Soils, 27, 236-241, 1998. 
Falloon, P., Smith, P., Szabó, J., and Pásztor, L.: Comparison of approaches for estimating carbon sequestration at the regional scale, Soil Use Manage., 18, 164-174, 2002.

Fatichi, S., Leuzinger, S. Reconciling observations with modeling: The fate of water and carbon allocation in a mature deciduous forest exposed to elevated $\mathrm{CO}_{2}$, Agr. Forest Meteorol., 174-175, 144-157, 2013.

Francaviglia, R., Coleman, K., Whitmore, A. P., Doro, L., Urracci, G., Rubino, M., and Ledda, L.: Changes in soil organic carbon and climate change - Application of the RothC model in agrosilvo-pastoral Mediterranean systems, Agr. Syst., 112, 48-54, 2012.

Garcia-Orenes, F., Cerdà, A., Mataix-Solera, J., Guerrero, C., and Bodí, M. B.: Effects of agricultural management on surface soil properties and soil-water losses in eastern Spain, Soil Till. Res., 106, 117-123, 2009.

Giorgi, F. and Lionello, P.: Climate change projections for the Mediterranean region, Global Planet. Change, 63, 90-104, 2008.

Guo, L., Falloon, P., Coleman, K., Zhou, B., Li, Y., Lin, E., and Zhang, F.: Application of the RothC model to the results of longterm experiments on typical upland soils in northern China, Soil Use Manage., 23, 63-70, 2007.

Hashimoto, S., Ugawa, S., Morisada, K., Wattenbach, M., Smith, P., and Matsuura, Y.: Potential carbon stock in Japanese forest soils - simulated impact of forest management and climate change using the CENTURY model, Soil Use Manage., 28, 45-53, 2012.

Hastie, T., Tibshirani, R., and Friedman, J.: The elements of statistical learning: data minng, interference and prediction, Springer Series in Statistics, Springer Verlag, Spain, 2001.

ICA: Modelo Digital de Elevaciones, 100 m, CD-ROM, Sevilla: Instituto de Cartografía de Andalucía, Consejería de Obras Públicas y Transportes (Junta de Andalucía), 1999.

IPCC: Climate Change 2007, The Physical Science Basis, Cambridge/New York: Cambridge University Press, 2007.

IUSS Working Group WRB: World Reference Base for Soil Resources 2006. World Soil Resources Reports No. 103, FAO, Rome.

Janssens, I. A., Freibauer, A., Schlamadinger, B., Ceulemans, R., Ciais, P., Dolman, A. J., Heimann, M., Nabuurs, G.-J., Smith, P., Valentini, R., and Schulze, E.-D.: The carbon budget of terrestrial ecosystems at country-scale - a European case study, Biogeosciences, 2, 15-26, doi:10.5194/bg-2-15-2005, 2005.

Janssen, R., Goosena, H., Verhoevenb, M. L, Verhoevenb, J. T. A., Omtzigta, A. Q. A., and Maltby, E.: Decision support for integrated wetland management, Environ. Modell. Softw., 30, 215229,2005

Jobbágy, E. G. and Jackson, R. B.: The vertical distribution of soil carbon and its relation to climate and vegetation, Ecol. Appl., 10, 423-436, 2000.

Jones, C., McConnell, C., Coleman, K., Cox, P., Falloon, P., Jenkinson, D., and Powlson D.: Global climate change and soil carbon stocks; predictions from two contrasting models for the turnover of organic carbon in soil, Glob. Change Biol., 11, 154-166, 2005.

Jordán, A. and Zavala, L. M.: Obtención de Indicadores a partir de la base de perfiles de suelo para su aplicación a la modelización climática, Unpublished technical report, Sevilla, Consejería de Medio Ambiente, Junta de Andalucía, 2009.
Kirschbaum, M. U. F.: Will changes in soil organic matter act as a positive or negative feedback on global warming?, Biogeochemistry, 48, 21-51, 2000.

Lal, R.: Soil carbon sequestration to mitigate climate change, Geoderma, 123, 1-22, 2004.

Lovett, G. M., Cole, J. J., and Pace, M. M.: Is Net Ecosystem Production Equal to Ecosystem Carbon Accumulation?, Ecosystems, 9, 1-4, 2006.

Lucht, W., Schaphoff, S., Erbrecht, T., Heyder, U., and Cramer, W. Terrestrial vegetation redistribution and carbon balance under climate change, Carbon Balance and Management, 1, 1-7, 2006.

Lugato, E. and Berti, A.: Potential carbon sequestration in a cultivated soil under different climate change scenarios: A modelling approach for valuating promising management practices in north-east Italy, Agr. Ecosyst. Environ., 128, 97-103, 2008.

Martín, A., Díaz-Raviña, M., and Caballas, T.: Short and mediumterm evolution of soil properties in Atlantic forest ecosystems affected by wildfires, Land Degrad. Develop., 23, 427-439, 2012.

Mitchell, T. D., Carter, T. R., Jones, P. D., Hulme, M., and New, M.: A comprehensive set of high-resolution grids of monthly climate for Europe and the globe: the observed record (1901-2000) and 16 scenarios (2001-2100). Working Paper 55, Norwich, Tyndall Centre for Climate Change Research, University of East Anglia, 2004.

Mondini, C., Coleman, K., and Whitmore, A. P.: Spatially explicit modelling of changes in soil organic $\mathrm{C}$ in agricultural soils in Italy, 2001-2100: Potential for compost amendment, Agr. Ecosyst. Environ., 153, 24-32, 2012.

Moreira, J. M.: Mapas de usos y coberturas vegetales del suelo de Andalucía, Escala 1/25,000, Guía Técnica, Sevilla, Consejería de Medio Ambiente, Junta de Andalucía, 2007.

Muñoz-Rojas, M.: Modelling carbon sequestration capacity in Medierranean soils, Ph.D. thesis, University of Seville, Spain, 169 pp., 2012.

Muñoz-Rojas, M., De la Rosa, D., Zavala, L. M., Jordán, A., and Anaya-Romero, M.: Changes in land cover and vegetation carbon stocks in Andalusia, Southern Spain (1956-2007), Sci. Total Environ., 409, 2796-2806, 2011.

Muñoz-Rojas, M., Jordán, A., Zavala, L. M., De la Rosa, D., AbdElmabod, S. K., and Anaya-Romero M.: Organic carbon stocks in Mediterranean soil types under different land uses (Southern Spain), Solid Earth, 3, 375-386, 2012a.

Muñoz-Rojas, M., Jordán, A., Zavala, L. M., De la Rosa, D., AbdElmabod, S. K., and Anaya-Romero, M.: Impact of land use and land cover changes on organic $\mathrm{C}$ stocks in Mediterranean soils (1956-2007), Land Degrad. Dev., doi:10.1002/ldr.2194, 2012 b.

Nakicenovic, N., Alcamo, J., Davis, G., de Vries, B., Fenhann, J., Gaffin, S., Gregory, K., Grübler, A., Jung, T. Y., Kram, T. La Rovere, E.L., Michaelis, L., Mori, S., Morita, T., Pepper, W., Pitcher, H., Price, L., Riahi, K., Roehrl, A., Rogner, H. H., Sankovski, A., Schlesinger, M., Shukla, P., Smith, S., Swart, R., van Rooijen, S., Victor, N., and Dadi, Z.: IPCC Special Report on Emissions Scenarios, Cambridge and New York: Cambridge University Press, 599 pp., 2000.

Oliveira, S., Oehler, F., San-Miguel-Ayanza, J., Camia, A., and Pereira, J. M. C.: Modeling spatial patterns of fire occurrence in Mediterranean Europe using multiple regression and Random Forest, Forest Ecol. Manag., 275, 117-129, 2012. 
Parton, W. J., Schimel, D. S., Cole, C. V., and Ojima, D. S.: Analysis of factors controlling soil organic matter levels in Great Plains grasslands, Sci. Soc. Am. J., 51, 1173-1179, 1987.

Paustian, K., Elliott, E. T., and Killian, K.: Modeling soil carbon in relation to management and climate change in some agroecosystems in central North America, in: Soil Processes and the Carbon Cycle, edited by: Lal, R., Kimble, J. M., Follett, R. F., and Stewart, B. A., Boca Raton, FL, USA, CRC Press, 459-471, 1997.

Powlson, D.: Will soil amplify the climate change?, Nature, 298, 156-159, 2005.

Rodriguez-Murillo, J. C.: Organic carbon content under different types of land use and soils in Peninsular Spain, Biol. Fertil. Soils, 33, 53-61, 2001.

Smith, J., Smith, P., Wattenbach, M., Zaehle, S., Hiederer, R., Jones, R. J. A., Montanarella, L., Rounsevell, M. D. A., Reginster, I., and Ewert, F.: Projected changes in mineral soil carbon of European croplands and grasslands, 1990-2080, Glob. Change Biol., 11, 2141-2152, 2005.

SPSS Inc.: PASW Statistics 18.0, Chicago, IL, 2009.

Tarnocai, C., Canadell, J. G., Schuur, E. A. G., Kuhry, P., Mazhitova, G., and Zimov, S.: Soil organic carbon pools in the northern circumpolar permafrost region, Global Biogeochem. Cy., 23, GB2023, doi:10.1029/2008GB003327, 2009.

Van Vuuren, D., Kok, M., Girod, B., and Lucas, P.: Scenarios in Global Environmental Assessments: Key characteristics and lessons for future use, Global Environ. Chang, 22, 4, 884-895, 2012.
Viaud, V., Angers, D. A., and Walter, C.: Towards landscape-scale modeling of soil organic matter dynamics in agroecosystems, Soil Sci. Soc. Am J, 74, 1-14, 2010.

Wan, Y., Lin, E., Xiong, W., Li, Y., and Guo, L.: Modeling the impact of climate change on soil organic carbon stock in upland soils in the 21st century in China, Agr. Ecosyst. Environ., 141, 23-31, 2011.

Yang, X., Yan, D., Zeng, L., Wu, M.: Wu Correlation of Root Structures and Soil Properties in the Near-Surface Soil of Three Forest Types in the Southern Mountains of Henan Province, China, J. Agr. Sci. Appl., 1, 79-85, 2012.

Zaehle, S., Bondeau, A., Carter, T. R., Cramer, W., Erhard, M., Prentice, I. C., Reginster, I., Rounsevell, M. D. A., Sith, S., Smith, B., Smith, P. C., and Sykes, M.: Projected changes in terrestrial carbon storage in Europe under climate and land-use change, 1990-2100, Ecosystems, 10, 380-401, 2007.

Zhang, J., Song, C., and Yang, W.: Temperature sensitivity of soil respiration and its effecting factors in the different land use (in Chinese), Acta Scientiae Circumstantiae, 25, 1537-1542, 2005.

Zhang, W., Wang, X., and Wang, S.: Addition of External Organic Carbon and Native Soil Organic Carbon Decomposition: A Meta-Analysis, PLoS ONE, 8, e54779, doi:10.1371/journal.pone.0054779 2013. 